\title{
SUMBER-SUMBER PERTUMBUHAN OUTPUT PERIKANAN DALAM PEREKONOMIAN INDONESIA PERIODE 1990-2000: Pendekatan Analisis Input-Output Menggunakan Metode Dekomposisi Faktor.
}

\author{
Tajerin $^{1}$
}

\begin{abstract}
ABSTRAK
Kajian ini bertujuan untuk mengetahui sumber-sumber pertumbuhan output perikanan dan perubahannya yang terjadi selama periode analisis. Data yang digunakan merupakan data sekunder dari Tabel Input Output Tahun 1990, 1995 dan 2000 yang disusun oleh Badan Pusat Statistik. Analisis data dilakukan menggunakan kerangka model input-output dengan pendekatan dekomposisi faktor. Hasil kajian menunjukkan bahwa pada periode 1990-1995, pertumbuhan output perikanan primer dan perikanan sekunder didominasi sumber perubahan permintaan akhir domestik, sedangkan pada periode 1995-2000 didominasi sumber perluasan ekspor. Berdasarkan kontribusi terhadap sumber pertumbuhan output total, diketahui bahwa selama periode analisis (1990-2000) belum terjadi (tengah berlangsung) perubahan struktur dari perekonomian yang didominasi kelompok perikanan primer kepada kelompok perikanan sekundernya. Untuk meningkatkan kinerja pertumbuhan output perikanan primer dan perikanan sekunder terkait dengan perubahan strukturnya, diperlukan dukungan penguasaan terknologi yang lebih maju dan lebih mendorong perluasan ekspor bersamaan dengan upaya meningkatkan substitusi impor.
\end{abstract}

Kata Kunci: Pertumbuhan Output, Perikanan, Industri Pengolahan.

Abstract: Sources of Fisheries Output Growth in the Indonesian Economy During 1990-2000: And Input-Output Analysis Approach Using the Decomposition Factor Method. By: Tajerin.

This study was primarily aimed to find out the sources of fisheries' output growth and changes occured to this sector during the analyzed period. Secondary data used in this research were derived from the 1990, 1995 and 2000 I-O tables composed by Central Bureau of Statistics (CBS). Analysis carried out by I-O model framework with factor decomposition approach. Results of the study indicated that during the $1990-1995$ period, both primary and secondary fisheries' output were dominated by changes in the final demand, while during the 1995-2000 period, it was dominated by export expansion. Based on its contribution towards total output growth, during the analysis period (1990 - 2000), fisheries sector had not been experiencing structural changes from a primary-fisheries-dominated economy to secondary-fisheries-dominated economy. In order to increase the performance of primary and secondary fisheries output growth related to the structural changes, more advanced technologies, support for more export expansion balanced by the efforts to promote import substitution are required.

Keywords: Output Growth, Fisheries, Processing Industry.

\footnotetext{
${ }^{1}$ Peneliti pada Balai Besar Riset Sosial Ekonomi Kelautan dan Perikanan

JI. KS. Tubun Petamburan VI, Jakarta 10260

Telp. $02153650162 /$ Fax. 02153650159
} 


\section{PENDAHULUAN}

Globalisasi dalam bidang ekonomi seperti yang tengah bergulir saat ini, telah memberikan banyak dampak bagi negaranegara yang terlibat didalamnya, yang secara langsung maupun tidak langsung telah mempengaruhinya kondisi perekonomiannya. Salah satu dampak globalisasi tersebut adalah kuatnya keterkaitan ekonomi suatu negara terhadap negara lain serta bebasnya mobilisasi faktor produksi termasuk modal. Dampak globalisasi ini memaksa Indonesia harus menghadapi krisis ekonomi yang berkepanjangan (Choeryanto, 2002). Dalam menghadapi krisis tersebut Indonesia perlu membuat strategi yang lebih mengarah kepada kebangkitan perekonomian Indonesia melalui kekuatan pembangunan yang berakar pada perekonomian di dalam negeri (domestik), sehingga dicapai 'penggarapan' secara maksimum dengan menggunakan sumber-sumber yang ada secara efisien (Baran dalam Jinghan, 2000; Meier and Baldwin dalam Jinghan, 2000).

Perikanan dan industri pengolahan hasil perikanan merupakan sektor yang memiliki keunggulan kompetitif, karena berbasiskan sumberdaya alam dan berakar pada perekonomian domestik serta dibangun melalui penerapan ilmu pengetahuan dan teknologi (Dahuri, 2003). Melalui pengelolaan secara tepat dan dengan kebijakan yang berpihak kepada pembangunan perikanan, memungkinkan terciptanya keterkaitan ekonomi yang kuat bagi sektor perikanan dengan industri pengolahan hasil perikanan dan sektor-sektor lainnya, sehingga pada gilirannya dapat tercipta "pemanenan" yang paling efisien dan mampu memberikan kontribusi maksimal bagi kemakmuran bangsa (Dahuri, 1999a; 1999b).

Secara empiris, lemahnya keterkaitan ekonomi antara perikanan dan industri pengolahan hasil perikanan terbukti telah menjadi salah satu penyebab penurunan utilitas dan kapasitas produksi dari kelompok perikanan sekunder serta hilangnya kesempatan untuk meningkatkan kinerja kelompok perikanan primer secara nyata (Nikijuluw, 2005). Oleh karena itu, agar "pemanenan" paling efisien dan kontribusi maksimal tersebut dapat tercipta maka perikanan sebagai kelompok primer haruslah diintegrasikan secara tepat dalam suatu kerangka sistem bisnis dengan sektor industri pengolahan hasil perikanan sebagai kelompok perikanan sekundernya. Pengintegrasian tersebut di antaranya dapat dilakukan melalui penggunaan sumber-sumber pertumbuhan output yang memberikan dorongan perekonomian sektor hulu maupun hilir, sehingga pada gilirannya dapat menyebabkan terjadinya transformasi (perubahan) struktural dari perekonomian sektor perikanan "dalam arti luas" yang semula secara proporsional didominasi kelompok perikanan primer kemudian didominasi kelompok perikanan sekunder. Secara teoritis, pertumbuhan ekonomi yang tinggi akan berkaitan dengan perubahan strukturnya, oleh karenanya terjadinya perubahan struktur tersebut merupakan salah satu indikator makro ekonomi suatu sektor telah tumbuh dengan baik (Susanti et al., 1999).

Keberhasilan meningkatkan pertumbuhan output tersebut akan sangat ditentukan oleh hal-hal yang bersifat internal maupun eksternal. Secara internal, perikanan dan industri pengolahan hasil perikanan masih dihadapkan oleh rendahnya tingkat pemanfaatan sumberdaya dan teknologi, tingginya tingkat kemiskinan, daya serap kesempatan kerja tinggi namun produktivitas ekonominya rendah, minat investasi terutama dalam skala menengah dan besar yang relatif rendah (Kusumastanto, 2001). Sementara itu, secara eksternal peningkatan kontribusi ekonomi perikanan maupun industri pengolahan hasil perikanan tersebut tentunya tidak terlepas dari pengaruh kebijakankebijakan ekonomi.

Dari paparan di atas, tampak bahwa di satu sisi terdapat harapan besar pentingnya 
mendorong kontribusi perikanan dan industri pengolahan hasil perikanan bagi pemulihan perekonomian Indonesia, namun di sisi lain baik faktor internal maupun eksternal masih sangat membebani laju pertumbuhan output yang semestinya dapat diciptakan. Untuk itu, kajian ini dilakukan dengan tujuan mengetahui sumber-sumber pertumbuhan output perikanan dan industri pengolahan hasil perikanan; dan kecenderungan pergeseran (perubahan) struktur ekonomi dari dominasi kontribusi perikanan primer ke perikanan sekunder yang terjadi selama periode 19902000.

\section{METODOLOGI}

\section{Jenis dan Sumber Data}

Data yang digunakan dalam kajian ini adalah data sekunder dari sumber buku Tabel Input-Ouput (I-O) transaksi total atas dasar harga produsen untuk Tahun 1990, 1995 dan 2000 yang disusun oleh Badan Pusat Statistik (1994, 1999, 2004). Agar dapat merekam peranan sektor perikanan dan industri pengolahan hasil perikanan, dalam kajian ini digunakan tabel I-O menurut klasifikasi $161 \mathrm{x}$ 161 sektor untuk tahun 1990; 172 x 172 sektor untuk tahun 1995; dan 175 x 175 sektor untuk tahun 2000. Namun mengingat klasifikasi matrik tabel-tabel I-O tersebut tidak sama, pada tahap awal dilakukan konversi klasifikasi matriks Tabel I-O Tahun 1995 dan 2000 ke dalam klasifikasi matrik tabel I-O tahun 1990 yang memiliki klasifikasi terendah (161 x 161 sektor). Setelah semua tabel I-O yang digunakan menjadi sama matriksnya, tahap selanjutnya dilakukan proses pengklasifikasian kembali dengan cara mengagregasi sektor-sektor dari tabel-tabel I-O dengan klasifikasi matriks sebesar $161 \mathrm{x}$

Tabel 1. Pengklasifikasian Sektor-Sektor dari Tabel Input-Output yang Digunakan dalam Kajian.

Table 1. Sectors Classification from Input-Output Table Used in the Analysis.

\begin{tabular}{|c|c|c|c|c|}
\hline \multirow[t]{2}{*}{$\begin{array}{l}\text { Sektor/ } \\
\text { Sectors }\end{array}$} & \multirow[t]{2}{*}{ Deskripsi/ Description } & \multicolumn{3}{|c|}{$\begin{array}{l}\text { Sektor-Sektor dalam Tabel Input-Output/ } \\
\text { Sectors in Input-Output Table }\end{array}$} \\
\hline & & 1990 & 1995 & 2000 \\
\hline 1 & $\begin{array}{l}\text { Pertanian non perikanan/ } \\
\text { Agriculture non fisheries } \\
\text { Perikanan primer/ Primary } \\
\text { fisheries: }\end{array}$ & $1-28$ & $1-31$ & $1-30$ \\
\hline 2 & $\begin{array}{l}\text { Perikanan laut dan hasil perairan } \\
\text { laut lainnya/ Marine fisheries and } \\
\text { other marine resources }\end{array}$ & 29 & $\left.32 ; 34 L_{90}{ }^{*}\right)$ & $\left.31 ; 33 L_{00}{ }^{* * *}\right)$ \\
\hline 3 & $\begin{array}{l}\text { Perikanan darat dan hasil } \\
\text { perairan darat lainnya/ } \\
\text { Freshwater fisheries and other } \\
\text { resources }\end{array}$ & 30 & $33 ; 34 \mathrm{D}_{90}{ }^{* *}$ & $32 ; 33 \mathrm{D}_{00}^{* * * *)}$ \\
\hline 4 & $\begin{array}{l}\text { Pertambangan dan penggalian/ } \\
\text { Mining and quarrying } \\
\text { Perikanan Sekunder/ } \\
\text { Secondary fisheries: }\end{array}$ & $32-34$ & $36-48$ & $35-48$ \\
\hline 5 & $\begin{array}{l}\text { Industri pengeringan dan } \\
\text { penggaraman ikan dan biota } \\
\text { perairan lainnya/ Drying and } \\
\text { salting of fish and other } \\
\text { resources industries }\end{array}$ & 31 & 53 & 53 \\
\hline
\end{tabular}


Lanjutan ( tabel 1)/Continue (table1).

\begin{tabular}{|c|c|c|c|c|}
\hline \multirow[t]{2}{*}{$\begin{array}{l}\text { Sektorl } \\
\text { Sectors }\end{array}$} & \multirow[t]{2}{*}{ Deskripsi/ Description } & \multicolumn{3}{|c|}{$\begin{array}{l}\text { Sektor-Sektor dalam Tabel Input-Output/ } \\
\text { Sectors in Input-Output Table }\end{array}$} \\
\hline & & 1990 & 1995 & 2000 \\
\hline 6 & $\begin{array}{l}\text { Industri pengolahan dan } \\
\text { pengawetan ikan dan biota } \\
\text { perairan lainnya/ Processing and } \\
\text { preserving industries of fish and } \\
\text { other biota }\end{array}$ & 48 & 54 & 54 \\
\hline 7 & $\begin{array}{l}\text { Industri pengolahan hasil } \\
\text { pertanian non perikanan/ } \\
\text { Agriculture non fisheries } \\
\text { processing industries }\end{array}$ & $\begin{array}{r}47-47 \\
49-83\end{array}$ & $\begin{array}{r}49-52 \\
55-91\end{array}$ & $\begin{array}{r}49-52 \\
55-93\end{array}$ \\
\hline 8 & $\begin{array}{l}\text { Industri pengolahan lainnya/ } \\
\text { Other processing industries }\end{array}$ & $84-131$ & $92-139$ & $94-141$ \\
\hline 9 & $\begin{array}{l}\text { Jasa-jasa dan lainnya/ Services } \\
\text { and others }\end{array}$ & $132-161$ & $35 ; 140-172$ & $34 ; 142-175$ \\
\hline
\end{tabular}

Keterangan/Remarks:

*) Proporsi output sektor 34 (udang) untuk sektor 29 sebesar $54,1 \%$ yang berasal dari udang hasil tangkapan di laut pada tahun 1995 (BPS, 2004b)/ Output proportion of sectors 34 (shrimp) for sectors 29 is 54.1\% from marine in 1995 (BPS, 2004b).

**) Proporsi output sektor 34 (udang) untuk sektor 30 sebesar $45,9 \%$ yang berasal dari udang hasil budidaya tambak dan tangkapan di perairan umum pada tahun 1995 (BPS, 2004b)/ Output proportion of sectors 34 (shrimp) for sectors 30 is $54.9 \%$ from brackish water pond and inland water in 1995 (BPS, 2004b).

***) Proporsi output sektor 34 (udang) untuk sektor 29 sebesar $54,5 \%$ yang berasal dari udang hasil tangkapan di laut pada tahun 2000 (BPS, 2004b)/ Output proportion of sectors 34 (shrimp) for sectors 29 is $54.5 \%$ from marine in 2000 (BPS, 2004b).

****) Proporsi output sektor 34 (udang) untuk sektor 30 sebesar $54,5 \%$ yang berasal dari udang hasil budidaya tambak dan tangkapan di perairan umum pada tahun 2000 (BPS, 2004b)/ Output proportion of sectors 34(shrimp) for sectors 30 is $54.5 \%$ from brackish water pond and inland in 2000 (BPS, 2004b).

Tahap selanjutnya, agar dapat diperbandingankan antara perubahan angka (nilai) riil dan nominal antar Tabel I-O yang digunakan, dalam kajian ini dilakukan konversi besaran harga berlaku dari masing-masing tabel I-O tersebut berdasarkan harga konstan tahun 1993 menurut "patokan" Produk Domestik Bruto (PDB) sebagai defaltornya. Pengaplikasian angka indeks PDB deflator tersebut dilakukan dengan menggunakan teknik seperti yang digunakan oleh Kaneko (1984) dan merupakan salah satu teknik yang dianjurkan oleh BPS (2000).

\section{Metoda Analisis Data}

Salah satu model yang secara luas digunakan untuk menganalisis struktur perekonomian baik di tingkat nasional maupun regional adalah model Input-Output (I-O). Dengan membandingkan dua atau lebih Tabel I-O dari periode yang berlainan dan dianalisis menggunakan pendekatan model I-O, dapat diketahui arah perubahan struktur dan perubahan faktor-faktor yang mempengaruhi pertumbuhan masing-masing sektor (Liu and Saal, 2000). Analisis mengenai sumbersumber pertumbuhan tersebut menjadi sangat 
penting karena dalam analisis pembangunan ekonomi tidak lagi sekedar mementingkan pertumbuhan ekonomi semata, tetapi juga melihat pembagian pertumbuhan antar faktor produksi dan sumber-sumber pertumbuhannya (Nazara, 1997).

Dalam kajian ini, analisis sumber-sumber pertumbuhan output dilakukan dengan menggunakan metode dekomposisi faktor struktural dari pertumbuhan output. Selanjutnya dengan metode tersebut dapat pula dianalisis pergeseran (perubahan) dominasi faktor-faktor (sumber-sumber) yang memberikan kontribusi terhadap pertumbuhan output di dalam perekonomian. Menurut Forssell (1988), metode tersebut sangat berguna dalam menyediakan sebuah kerangka kerja bagi penelaahan sumbersumber pertumbuhan output dan perubahan struktural dalam sebuah perekonomian.

Metode dekomposisi faktor yang digunakan dalam kajian ini adalah seperti yang diajukan oleh Chenery (1960) yang kemudian dikembangkan lebih lanjut oleh Akita (1991). Metoda ini secara luas telah digunakan untuk menganalisis perubahan struktur dan sumbersumber pertumbuhan ekonomi dari sisi permintaan. Diantaranya adalah oleh Akita (1991), Akita dan Hermawan (2000) dan Hayashi (2005) masing-masing untuk menganalisis perubahan struktur dan sumbersumber pertumbuhan ekonomi di Indonesia; dan Rashid dan Elameer (1999) untuk kasus di Malaysia; dan Liu and Saal (1998) untuk kasus di Afrika Selatan.

Metoda tersebut dimulai dengan persamaan identitas akuntansi dari permintaan dan penawaran, yang membuat model ini dapat menjelaskan perubahan diferensial pada produksi sektoral yang terdisagregasi sebagai sebuah ekspansi nonproporsional dari empat faktor, yaitu: (1) peningkatan permintaan domestik; (2) perubahan permintaan antara; (3) perluasan ekspor; dan (4) substitusi impor. Keempat faktor yang memberikan kontribusi terhadap output yang diperoleh berdasarkan formulasi pada kondisi sistem perekonomian terbuka, dimana keseimbangan material dasar antara permintaan dan penawaran dapat ditulis sebagai:

$$
X=W+D+E-M
$$

dimana $\mathrm{X}, \mathrm{D}, \mathrm{W}, \mathrm{E}$ dan $\mathrm{M}$ masing-masing menunjukkan vektor dari gross output, permintaan akhir domestik, permintaan antara, permintaan akhir luar negeri (ekspor) dan impor. Dengan catatan bahwa permintaan antara dari sektor ke-i dapat ditentukan dengan mengalikan matriks koefisien inputoutput dengan total output sektoral sebagai $\mathrm{W}=\mathrm{AX}$ dan $M=\hat{m}(W+D) \quad$ (dimana A adalah matriks koefisien input-output, dan $m$ adalah matriks diagonal rasio impor). Rasio impor itu sendiri dihitung dengan membagi impor dengan total penawaran domestik, atau $\hat{\mathrm{m}}=\mathrm{M}_{\mathrm{i}} / \mathrm{D}_{\mathrm{i}}+\mathrm{W}_{\mathrm{i}} \quad$ (Chenery, 1979), sehingga persamaan (1) dapat ditulis kembali sebagai:

$$
X=(I-\hat{m})(A X+D)+E
$$

Dengan menambah $\hat{p}=I-\hat{m}$ (dimana $\hat{p}$ merepresentasikan matriks diagonal penawaran domestik), dan bila $\mathrm{B}=(\mathrm{I}-\hat{\mathrm{p} A})^{-1}$ maka persamaan (2) dapat ditulis kembali menjadi :

$$
X=B \hat{p} D+E
$$

Dengan mengurangi nilai $X$ pada waktu $t$ tertentu $\left(X_{t}\right)$ dengan $X$ pada waktu awal $\left(X_{0}\right)$ sehingga dapat diukur dekomposisi output atau yang dikenal dengan " $\Delta$ decomposition measure" (seperti yang juga digunakan oleh Kubo dan Robinson, 1979),

$$
\Delta \mathrm{X}=\mathrm{X}_{\mathrm{t}}-\mathrm{X}_{\mathrm{o}}
$$

Dari persamaan (4), dekomposisi $\Delta X$ dapat diekspresikan sebagai berikut:

$$
\Delta X=B_{t} \hat{p}_{t} \Delta D+B_{t} \Delta E+B_{t} \hat{p}_{t} \Delta A X_{0}+B_{t} \Delta \hat{p}\left(A_{0} X_{0}+D_{0}\right)
$$


Dengan demikian metoda analisis dekomposisi terhadap sumber-sumber pertumbuhan output tersebut dapat difomulasi sebagai berikut: tahun awal/dasar dengan pembobotan di tahun tertentu/terminal; namun dalam prakteknya dapat pula dilakukan sebaliknya, sehingga dapat dirumuskan dalam persamaan 7 .

$$
\begin{aligned}
& \Delta X=B_{i}\left\{\left(p_{t}-p_{0}\right)\left(A X_{t}+D_{t}\right)+p_{0}\left(A-A_{0}\right) X_{t}+p_{0}\left(D_{t}-D_{0}\right)+\left(E_{t}-E_{0}\right)\right\} \\
& \Delta X=B_{0}\left\{\left(p_{t}-p_{0}\right)\left(A_{0} X_{0}+D_{0}\right)+p_{t}\left(A-A_{0}\right) X_{0}+p_{t}\left(D_{t}-D_{0}\right)+\left(E_{t}-E_{0}\right)\right\}
\end{aligned}
$$

dimana B adalah invers Leontief domestik; $p$ adalah struktur impor; $\mathrm{X}$ adalah jumlah output; $\mathrm{D}$ adalah permintaan domestik; $\mathrm{E}$ adalah jumlah output yang diekspor; sedangkan t dan 0 menunjukkan tahun dasar dan tahun terminal. Sehingga pertumbuhan output dapat didekomposisikan ke dalam empat sumber, yaitu:

(a) Substitusi impor (IS) atau dampak perubahan output yang berasal dari perubahan proporsi impor terhadap permintaan domestik di semua sektor yang harus dipenuhi oleh perekonomian domestik.

$\left\{B_{t}\left(p_{t}-p_{0}\right)\left(A X_{t}+D_{t}\right)\right\}$

(b) Perubahan teknologi (TC) atau dampak perubahan output yang bersumber dari perubahan koefisien input-output masing-masing sektor dalam perekonomian. $\left\{B_{t} p_{0}\left(A-A_{b}\right) X_{t}\right\}$

(C) Perubahan permintaan domestik (DD) atau dampak perubahan output yang bersumber dari perubahan permintaan domestik masing-masing sektor dalam perekonomian. $\left\{B_{t} p_{0}\left(D_{t}-D_{0}\right)\right\}$

(d) Perluasan ekspor (EE) atau dampak perubahan output yang bersumber dari perubahan permintaan ekspor masingmasing sektor dalam perekonomian .

$\left(E_{t}-E_{0}\right)$

Persamaan (6) di atas dirumuskan dengan menggunakan parameter struktur pada
Penggunaan kedua persamaan itu (persamaan 6 dan 7) akan menghasilkan angka yang berbeda. Oleh karena itu, dalam kajian ini sesuai dengan yang disarankan oleh Akita (1991) akan digunakan rata-rata sederhana dari kedua persamaan tersebut. Selanjutnya berdasarkan proporsi komponennya, perubahan permintaan domestik (DD) akan dipilah menjadi empat komponen, yaitu:

(1) Perubahan konsumsi rumah tangga (DD1).

(2) Perubahan konsumsi pemerintah (DD2).

(3) Pembentukan modal tetap (Dd3)

(4) Perubahan stock (DD4).

Dengan demikian baik persamaan (6) maupun (7) dapat disederhanakan menjadi:

$$
\begin{gathered}
\Delta X=I S+T C+(D D 1+D D 2+D D 3+ \\
D D 4)+E E
\end{gathered}
$$

Selanjutnya untuk mendapatkan persamaan dekomposisi faktor dari yang diukur berdasarkan "perubahan output" (X) menjadi "pertumbuhan output" (X/X), maka sisi kiri dan kanan pada persamaan (8) masingmasing dibagi dengan nilai $X$ periode awal.

\section{HASIL DAN PEMBAHASAN}

Untuk mengetahui sumber-sumber pertumbuhan output dan perubahan (pergeseran)-nya selama periode analisis, maka pemaparan analisis disajikan menurut periodesasi (periode 1990-1995 dan periode 1995-2000). Besarnya angka yang dihasilkan dari selisih di antara kedua periode tersebut 
dalam hal ini mencerminkan besarnya perubahan (pergeseran) yang terjadi dari masing-masing sektor yang dianalisis.

\section{Periode Pertama (1990-1995)}

Dari Tabel 2 (bagian A) dan Gambar 1 diketahui bahwa secara sektoral pada periode pertama (1990-1995), sumber pertumbuhan output yang terbesar (dominan) dari sektorsektor dalam perekonomian Indonesia kecuali sektor industri pengolahan dan pengawetan ikan adalah diperoleh dari kontribusi perubahan permintaan akhir domestik (DD), yaitu berkisar sebesar 54,32\% hingga $109,13 \%$, terutama yang diperoleh dari komponen perubahan konsumsi swasta (DD1) yang mencapai sebesar 33,02 - 105,85\%. Dengan demikian sektor-sektor dalam periode pertama ini sebagian besar merupakan sektorsektor yang sumber pertumbuhan outputnya diperoleh dari dominasi perubahan permintaan akhir domestik atau disebut sebagai domestic demand driven sectors.

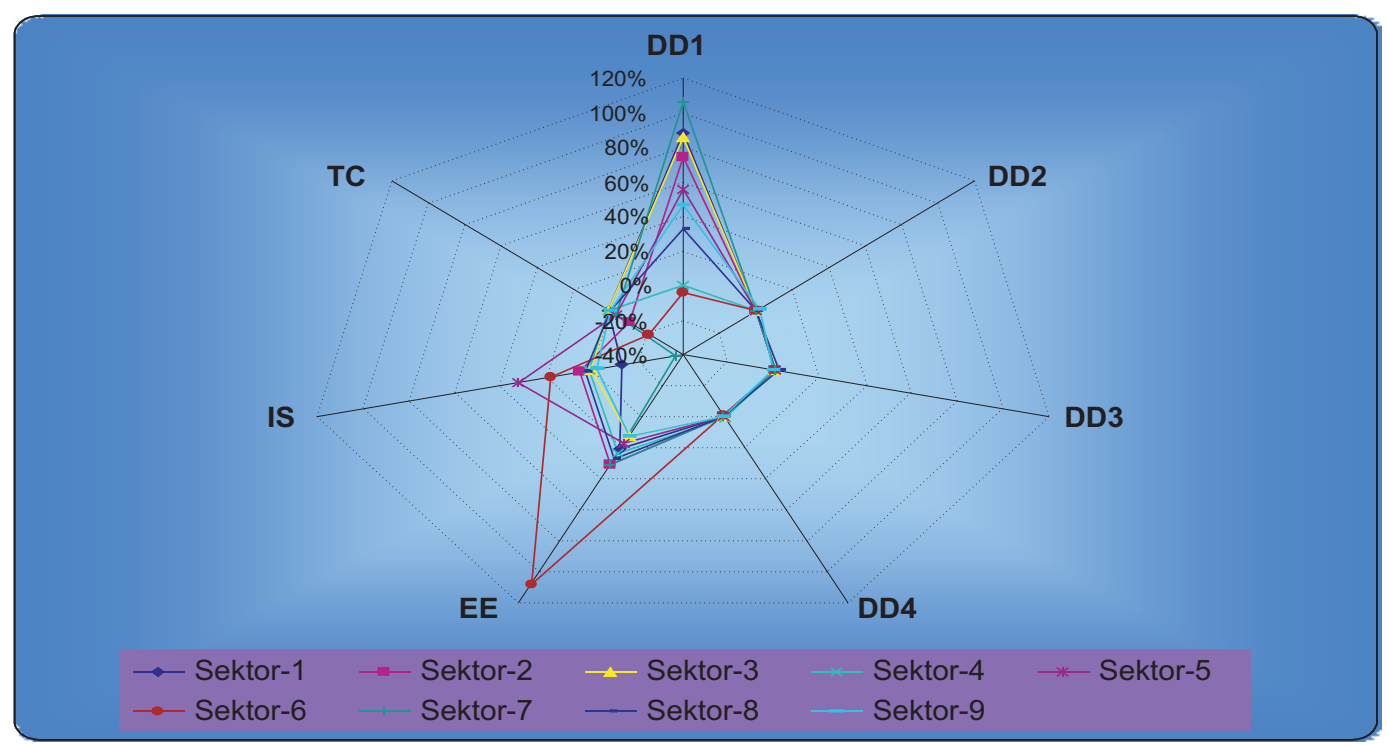

Gambar1. Diagram Sumber-Sumber Pertumbuhan Output dari Sektor-Sektor dalam Perekonomian Indonesia Tahun 1990-1995 (\% dari Pertumbuhan Output Sektoral).

Figure 1. Sources of Output Growth Diagram from Indonesian Economy Sectors During 1990-1995 (\% from Sector al Output Growth).

Keterangan/Remarks:

- Sektor-1/Sector 1 = Sektor pertanian non perikanan/Agriculture non fisheries.

- Sektor-2/Sector 2 = Sektor perikanan laut dan hasil perairan laut lainnya/Marine fisheries and other marine resources.

- Sektor-3/Sector 3 = Sektor perikanan darat dan hasil perairan darat lainnya/Freshwater fisheries and other marine resources.

- Sektor-4/Sector4 = Sektor pertambangan dan galian pemerintah/Government mining and quarrying.

- Sektor-5/Sector 5 = Sektor industri pengeringan ikan dan biota perairan lainnya/Drying and salting processing industries.

- Sektor-6/Sector 6 = Sektor industri pengolahan dan pengawetan ikan dan biota perairan lainnya/ Processing and preserving industries.

- Sektor-7/Sector 7 = Sektor industri pengolahan hasil pertanian non perikanan/Agriculture non-fisheries processing industries.

- Sektor-8/Sector 8 = Sektor industri pengolahan lainnya/Other processing industries.

- Sektor-9/Sector 9 = Sektor jasa-jasa dan lainnya/ Service and others. 


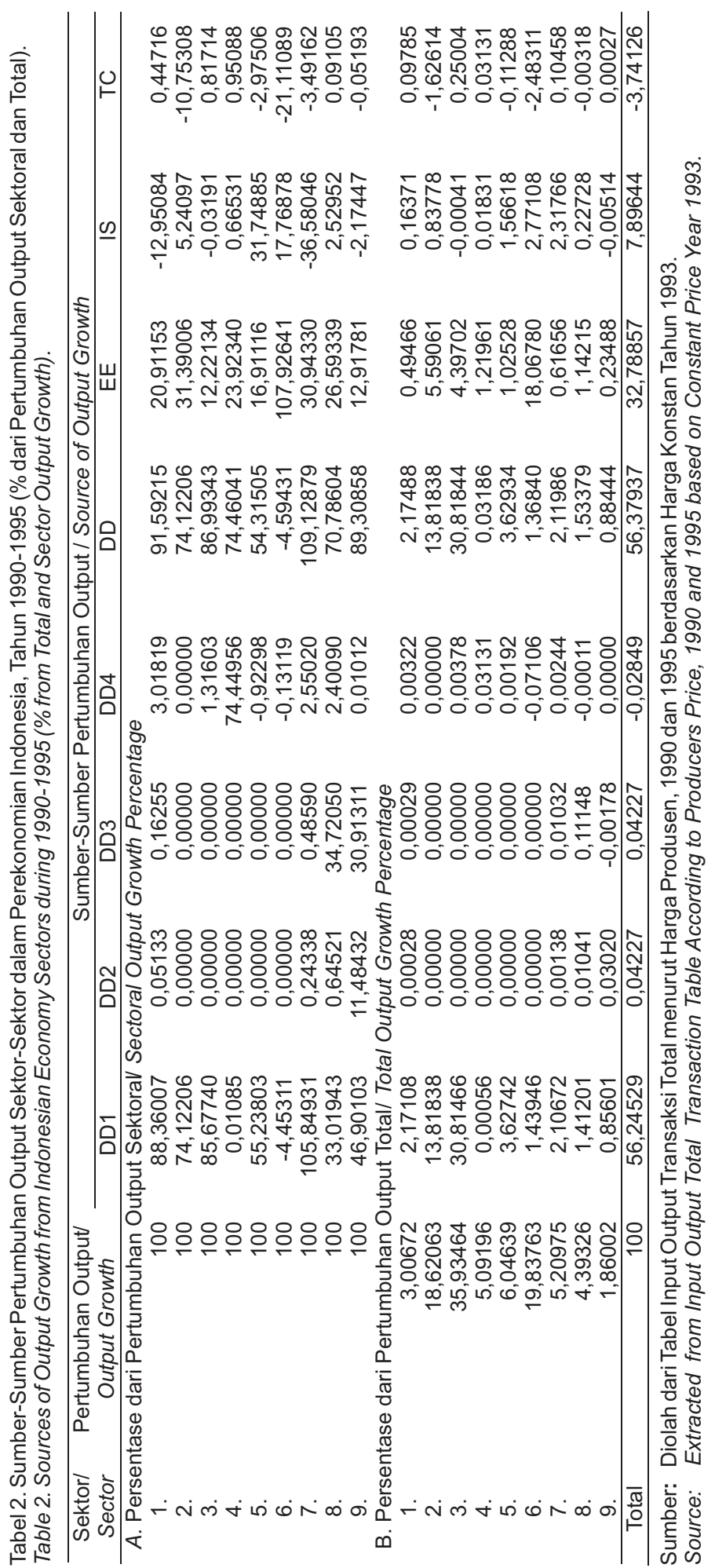

g

ฐิ

(2)

d

$\stackrel{2}{2}$

है

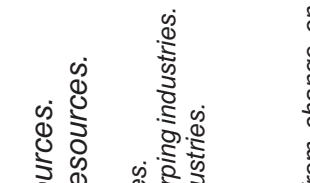

ธ

8

$\frac{\pi}{0}$

ह

की

ब. के

๑)

है फ ठठ

屯

के

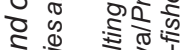

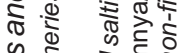

के के

ब

की

का के

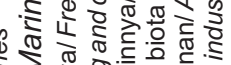

क

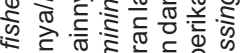

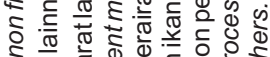

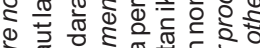

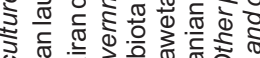

는

क人ष

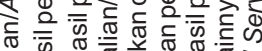

为

䨔

ब。

등 즁

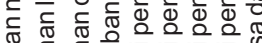

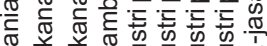

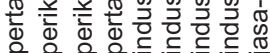

흫ㅎㅎㅎㅎㅎㅎㅎㅎㅎ

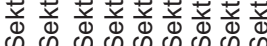

| || | | | | | | |

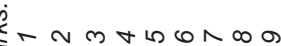

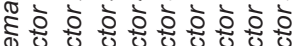

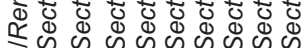
๙

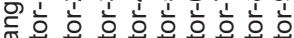

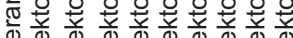

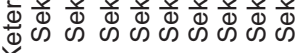


Dari sumber kontribusi DD tersebut, pertumbuhan output perikanan laut dan perikanan darat masing-masing sebesar $74,12 \%$ dan $86,99 \%$. Sedangkan untuk industri pengeringan dan penggaraman ikan di samping diperoleh dari sumber kontribusi DD sebesar $54,32 \%$, juga bersumber kontribusi perubahan substitusi impor (IS) yang tergolong besar, yaitu sebesar $31,75 \%$. Sementara untuk industri pengolahan dan pengawetan ikan memiliki sumber pertumbuhan output terbesarnya dari kontribusi perluasan ekspor (EE), yaitu sebesar $107,93 \%$.

Dari uraian tersebut, dapat diketahui bahwa kecuali sektor pengolahan dan pengawetan ikan yang pertumbuhan output terbesarnya bersumber dari perluasan ekspor $(E E)$, secara umum sektor-sektor yang terkait dengan perikanan (perikanan primer) dan industri pengolahan hasil perikanan (perikanan sekunder) merupakan sektorsektor yang pertumbuhan output terbesarnya bersumber dari dominasi kontribusi akhir domestik(DD).

Selanjutnya bila dilihat dari kontribusinya terhadap pertumbuhan output total perekonomian Indonesia seperti tertera pada Tabel 2 (bagian B), diketahui bahwa masingmasing sektor yang diamati memberikan kontribusi yang positif. Dari sembilan sektor yang diamati terdapat tiga sektor yang memiliki kontribusi positif relatif besar terhadap pertumbuhan output total. Ketiga sektor tersebut adalah sektor-sektor yang terkait dengan perikanan dan industri pengolahan hasil perikanan, yaitu perikanan darat, industri pengolahan dan pengawetan ikan, dan perikanan laut masing-masing sebesar 35,94\%, 19,84 dan 18,62\%; sedangkan enam sektor lainnya memiliki kontribusi positif relatif rendah, yaitu berkisar sebesar $1,86 \%$ hingga $6,05 \%$.

Selain itu, dari tabel 2 (bagian B) dan Gambar 2 dapat diketahui pula bahwa pada periode pertama (1990-1995) ini, perubahan

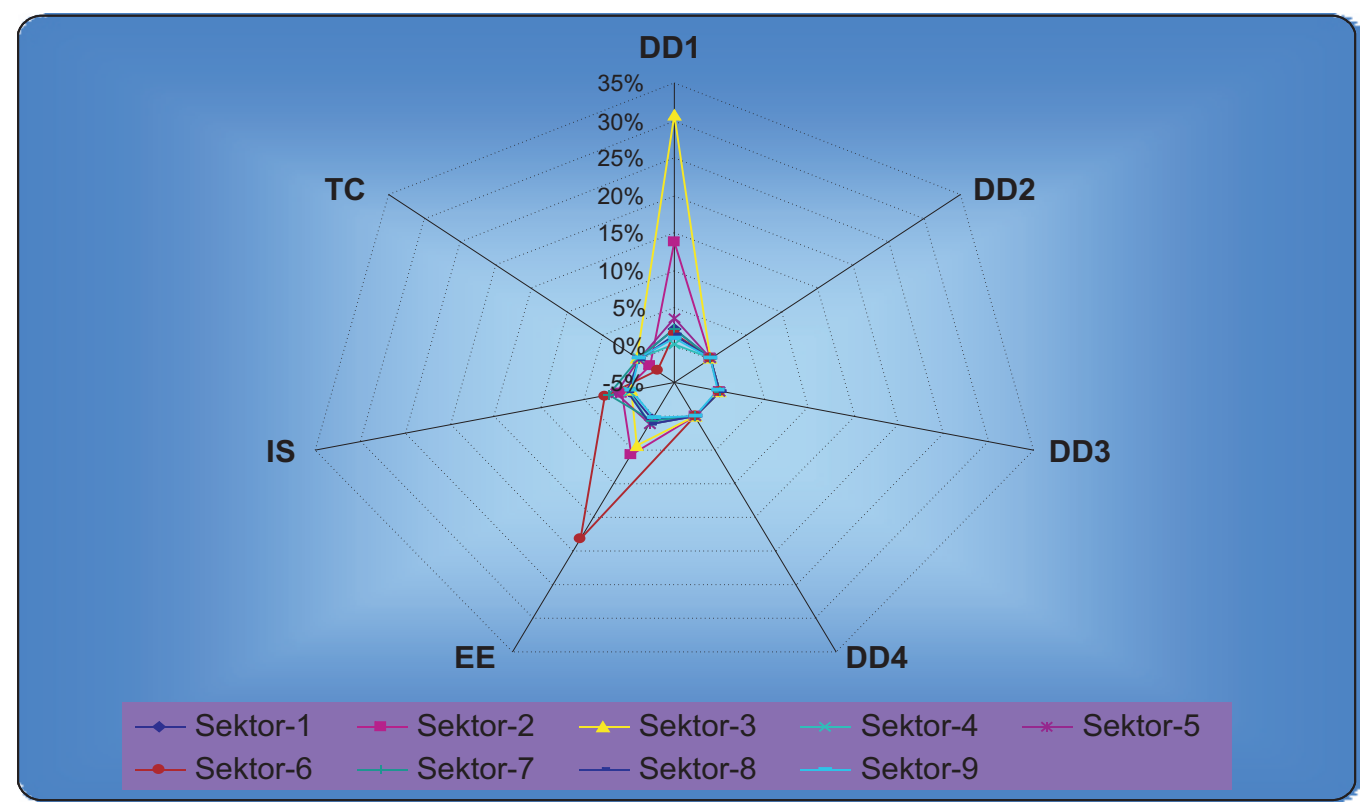

Gambar 2. Diagram Sumber-Sumber Pertumbuhan Output Total dari Sektor-Sektor dalam Perekonomian Indonesia Tahun 1990-1995 (\% dari Pertumbuhan Output Total).

Figure 2. Sources of Total Output Growth Diagram from the Indonesian Economy Sectors During 1990-1995 (\% of Total Output Growth). 
Keterangan/Remarks:

- Sektor-1/Sector 1 = Sektor pertanian non perikanan/Agriculture non fisheries.

- Sektor-2/Sector 2 = Sektor perikanan laut dan hasil perairan laut lainnya/Marine fisheries and other marine resources.

- Sektor-3/Sector 3 = Sektor perikanan darat dan hasil perairan darat lainnya/Freshwater fisheries and other marine resources.

- Sektor-4/Sector 4 = Sektor pertambangan dan galian pemerintah/Government mining and quarrying .

- Sektor-5/Sector 5 = Sektor industri pengeringan ikan dan biota perairan lainnya/Drying and salting processing industries.

- Sektor-6/Sector 6 = Sektor industri pengolahan dan pengawetan ikan dan biota perairan lainnya/ Processing and preserving industries.

- Sektor-7/Sector 7 = Sektor industri pengolahan hasil pertanian non perikanan/Agriculture non-fisheries processing industries.

- Sektor-8/Sector 8 = Sektor industri pengolahan lainnya/Other processing industries.

- Sektor-9/Sector 9 = Sektor jasa-jasa dan lainnya/ Service and others.

permintaan akhir domestik (DD) merupakan sumber pertumbuhan output total perekonomian Indonesia yang terbesar (dominan) dengan kontribusi sebesar 56,38\%. Perikanan laut dan perikanan darat merupakan dua sektor yang memberikan kontribusi terbesar terhadap pertumbuhan output total perekonomian Indonesia dari dominasi DD tersebut, yaitu masing-masing sebesar $30,82 \%$ dan $13,82 \%$ dari pertumbuhan output total. Urutan berikutnya disusul oleh industri pengolahan dan pengawetan ikan yaitu dengan kontribusi sebesar $3,63 \%$.

Pada periode pertama (1990-1995), perluasan ekspor (EE) merupakan sumber pertumbuhan output total perekonomian Indonesia yang tidak tergolong dominan, karena masih lebih rendah dibandingkan sumber perubahan permintaan akhir domestik(DD), yaitu dengan kontribusi sebesar $32,89 \%$. Sektor industri pengolahan dan pengawetan ikan merupakan sektor yang memberikan kontribusi terbesar terhadap pertumbuhan output total yang bersumber dari perluasan ekspor (EE), yaitu sebesar 18,07\%. Dengan kata lain pada periode pertama, sektor ini merupakan export oriented sector. Urutan selanjutnya disusul oleh perikanan laut dan perikanan darat masing-masing dengan kontribusi sebesar $5,59 \%$ dan $4,40 \%$; sedangkan sektor lainnya hanya mampu memberikan kontribusi yang tergolong rendah terhadap EE, yaitu berkisar sebesar 0,23\% hingga $1,22 \%$.

Sementara itu, sumber substitusi impor (IS) hanya memberikan kontribusi yang relatif rendah dibandingkan dari sumber DD maupun $E E$, yaitu sebesar $7,90 \%$. Dua dari tiga sektor yang memberikan kontribusi relatif besar terhadap pertumbuhan output total yang bersumber dari perubahan subtitusi impor (IS) merupakan sektor yang terkait dengan industri pengolahan hasil perikanan. Kedua sektor tersebut adalah industri pengolahan dan pengawetan ikan $(2,77 \%)$ dan industri pengeringan dan penggaraman ikan (1,57\%).

Bila pada periode pertama ini, sumbersumber pertumbuhan output total perekonomian Indonesia dari DD, EE dan IS memberikan kontribusi yang positif (meningkatkan pertumbuhan output total), sebaliknya untuk perubahan teknologi (TC) sebagai sumber pertumbuhan output total justru memberikan kontribusi yang negatif (menurunkan pertumbuhan output total). Kontribusi negatif dari sumber perubahan teknologi(TC) ini sebesar $-3,74 \%$ dari pertumbuhan output total, terutama disumbang oleh industri pengolahan dan pengawetan ikan $(-2,48 \%)$, perikanan laut ($1,63 \%)$ dan industri pengeringan dan penggaraman ikan $(-0,11 \%)$. 


\section{Periode Kedua (1995-2000)}

Dari tabel 3 (bagian A) dan gambar 3 dapat diketahui bahwa pada periode kedua (1995-2000), sektor-sektor dalam perekonomian Indonesia sebagian besar memberikan kontribusi yang terbesar (dominan) terhadap perluasan ekspor (EE) sebagai sumber pertumbuhan output sektoralnya, atau disebut sebagai export oriented sectors. Sektor industri pengolahan dan pengawetan ikan merupakan sektor yang pertumbuhan output terbesarnya berasal dari dominasi sumber perluasan ekspor(EE), yaitu sebesar 177,84\%; sedangkan untuk perikanan darat, perikanan laut dan industri pengolahan dan pengawetan ikan, masing-

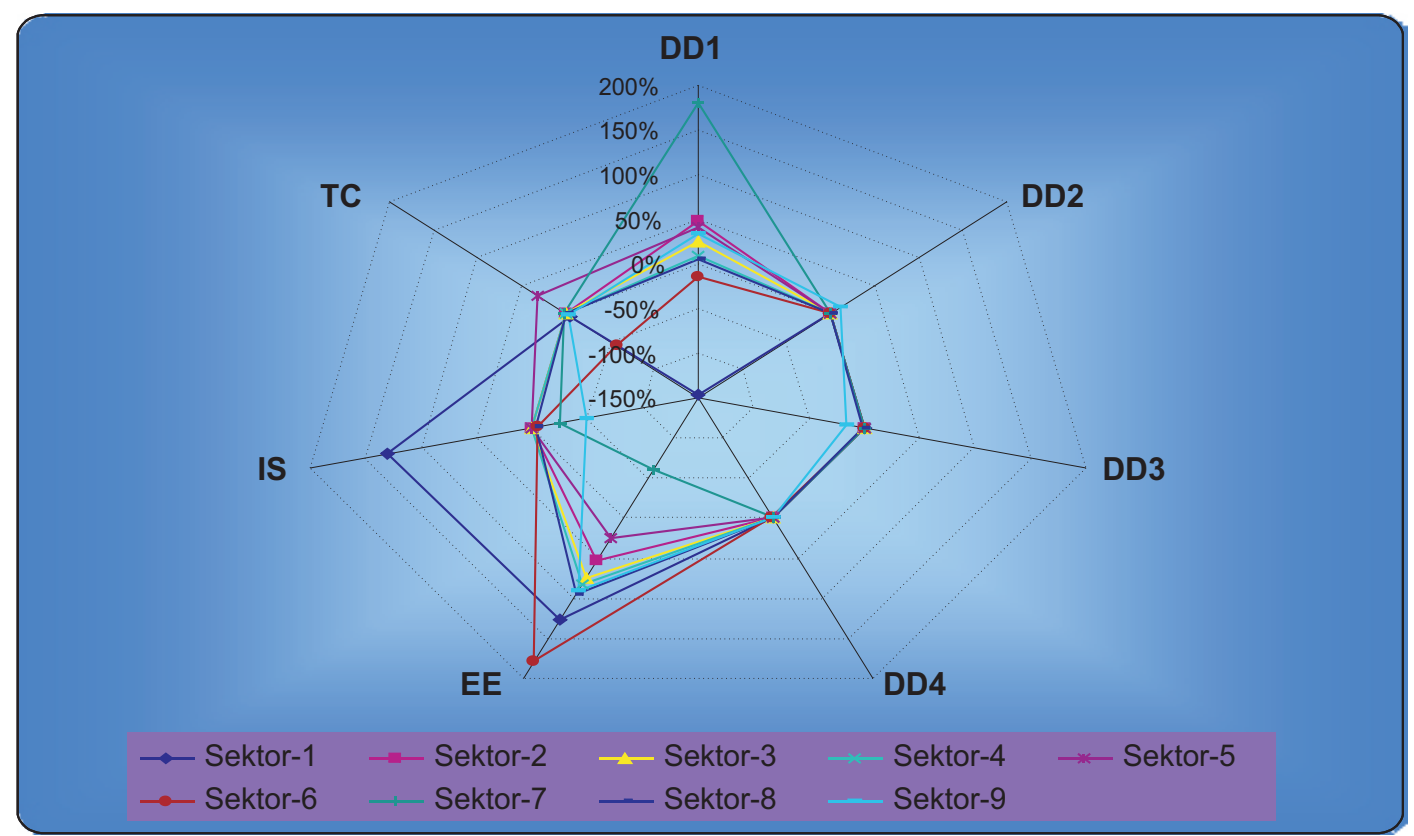

Gambar 3. Diagram Sumber-Sumber Pertumbuhan Output dari Sektor-Sekto dalam Perekonomian Indonesia Tahun 1995-2000 (\% dari Pertumbuhan Output Sektoral).

Figure 3. Sources of Output Growth Diagram from the Indonesian Economy Sectors During 1995-2000 (\% from Sectoral Output Growth).

Keterangan/Remarks:

- Sektor-1/Sector 1 = Sektor pertanian non perikanan/Agriculture non fisheries.

- Sektor-2/Sector 2 = Sektor perikanan laut dan hasil perairan laut lainnya/Marine fisheries and other marine resources.

- Sektor-3/Sector 3 = Sektor perikanan darat dan hasil perairan darat lainnya/Freshwater fisheries and other marine resources.

- Sektor-4/Sector 4 = Sektor pertambangan dan galian pemerintah/Government mining and quarrying

- Sektor-5/Sector 5 = Sektor industri pengeringan ikan dan biota perairan lainnya/Drying and salting processing industries.

- Sektor-6/Sector 6 = Sektor industri pengolahan dan pengawetan ikan dan biota perairan lainnya/ Processing and preserving industries.

- Sektor-7/Sector 7 = Sektor industri pengolahan hasil pertanian non perikanan/Agriculture non-fisheries processing industries.

- Sektor-8/Sector 8 = Sektor industri pengolahan lainnya/Other processing industries

- Sektor-9/Sector 9 = Sektor jasa-jasa dan lainnya/ Service and others. 


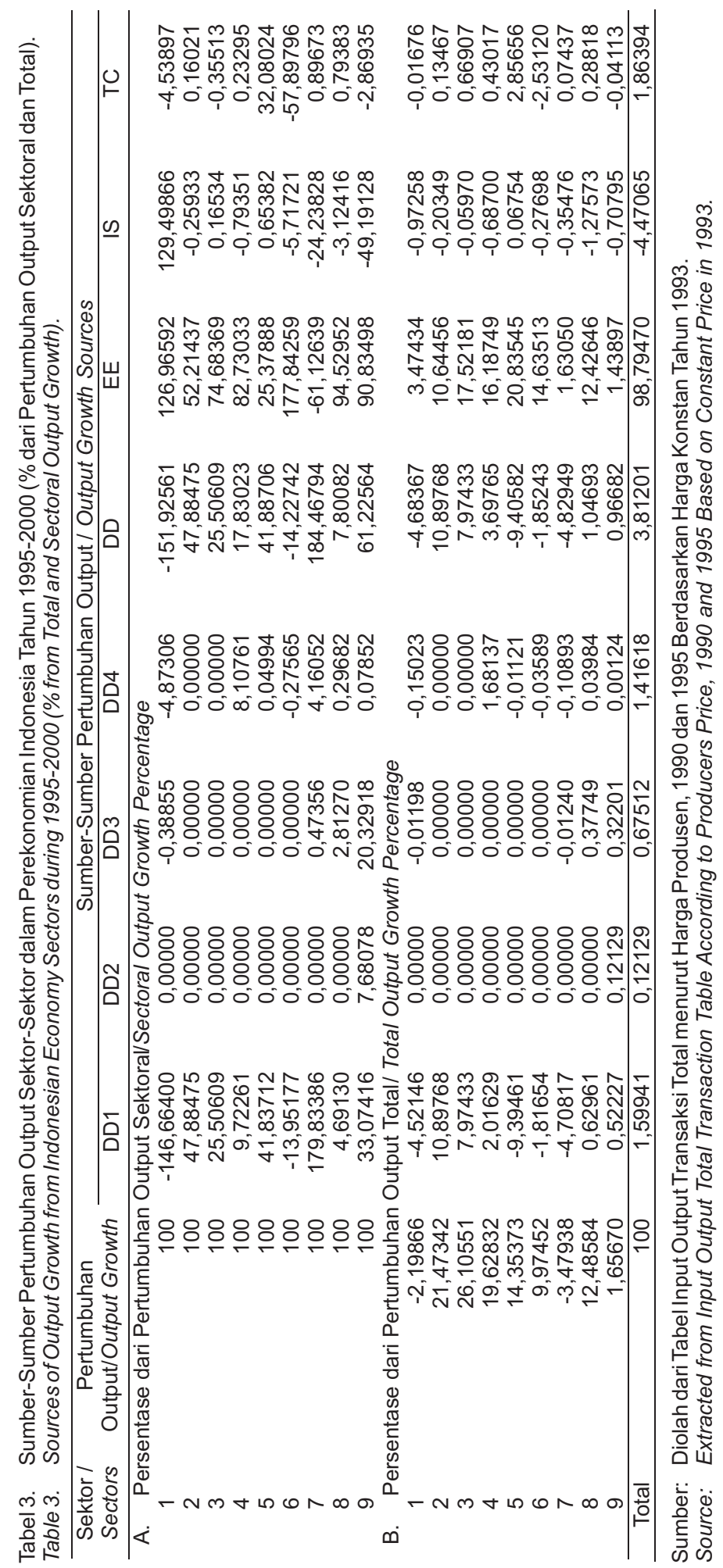


masing sebesar $74,68 \%, 52,21 \%$ dan $25,38 \%$ dari pertumbuhan output sektoralnya. Di samping dari sumber perluasan ekspor (EE), sektor perikanan laut memiliki perubahan permintaan akhir domestik (DD) sebagai sumber pertumbuhan output sektoralnya, yaitu sebesar $47,88 \%$. Sementara, sektor industri pengeringan dan penggaraman ikan tidak termasuk sebagai export oriented sectors, melainkan sebagai domestic demand driven sector karena pertumbuhan output sektoralnya didominasi (terbesar) dari sumber perubahan permintaan akhir domestik (DD) dengan kontribusi sebesar 41,89\%. Namun ternyata sektor ini memiliki sumber pertumbuhan output lainnya dengan kontribusi yang mendekati sama dengan kontribusi sumber DD, yaitu dari dari sumber perluasan ekspor (EE) sebesar 25,37\% dan sumber perubahan teknologi (TC) sebesar 32,08\%.
Selanjutnya bila dilihat dari kontribusinya terhadap pertumbuhan output total perekonomian Indonesia seperti tertera pada tabel 2 (bagian B), diketahui bahwa sebagian besar sektor-sektor (tujuh dari sembilan sektor) memberikan kontribusi yang positif terhadap pertumbuhan output total perekonomian Indonesia. Kontribusi positif terbesar disumbang oleh perikanan darat, yaitu sebesar $26,11 \%$ dari total $(100 \%)$ pertumbuhan output perekonomian, sedangkan untuk perikanan laut, industri pengeringan dan penggaraman ikan, industri pengolahan dan pengawetan ikan masingmasing memberikan kontribusi yang relatif besar, yaitu masing-masing sebesar $21,47 \%$, $14,35 \%$ dan $9,97 \%$.

Selain itu dari Tabel 3 (bagian B) dan gambar 4 diketahui pula bahwa pada periode kedua ini, perluasan ekspor (EE) merupakan sumber pertumbuhan output total

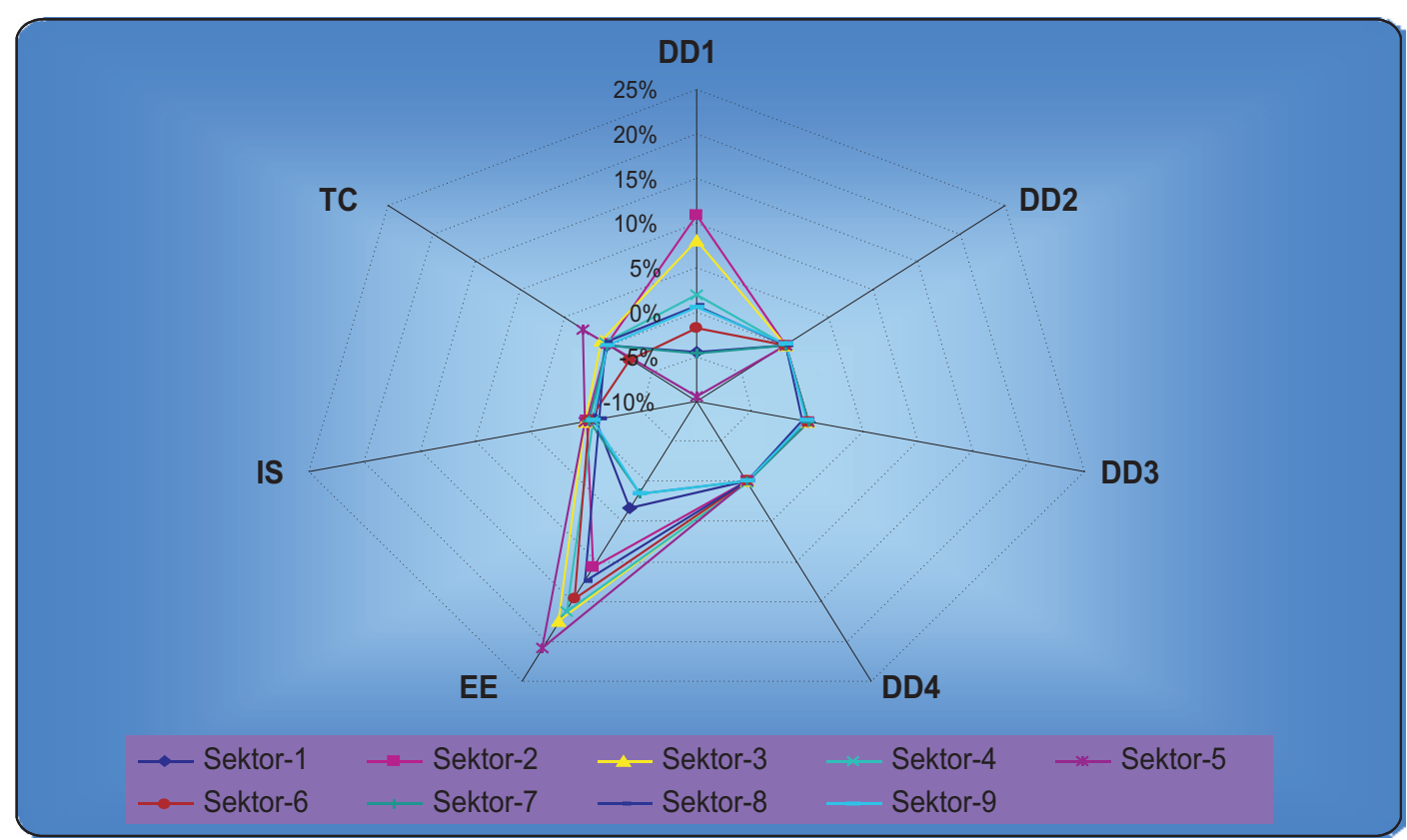

Gambar 4. Diagram Sumber-Sumber Pertumbuhan Output Total dari Sektor-Sektor dalam Perekonomian Indonesia Tahun 1995-2000 (\% dari Pertumbuhan Output Total).

Figure 4. Sources of Total Output Growth Diagram from the Indonesian Economy Sectors During 1995-2000 (\% of Total Output Growth). 
Keterangan/Remarks:

- Sektor-1/Sector 1 = Sektor pertanian non perikanan/Agriculture non fisheries.

- Sektor-2/Sector 2 = Sektor perikanan laut dan hasil perairan laut lainnya/Marine fisheries and other marine resources.

- Sektor-3/Sector 3 = Sektor perikanan darat dan hasil perairan darat lainnya/Freshwater fisheries and other marine resources.

- Sektor-4/Sector 4 = Sektor pertambangan dan galian pemerintah/Government mining and quarrying

- Sektor-5/Sector 5 = Sektor industri pengeringan ikan dan biota perairan lainnya/Drying and salting processing industries.

- Sektor-6/Sector6 $=$ Sektor industri pengolahan dan pengawetan ikan dan biota perairan lainnya/ Processing and preserving industries.

- Sektor-7/Sector 7 = Sektor industri pengolahan hasil pertanian non perikanan/Agriculture non-fisheries processing industries.

- Sektor-8/Sector 8 = Sektor industri pengolahan lainnya/Other processing industries.

- Sektor-9/Sector 9 = Sektor jasa-jasa dan lainnya/ Service and others.

perekonomian Indonesia yang dominan, yaitu dengan kontribusi sebesar 98,79\%. Kontribusi perluasan ekspor (EE) tersebut diberikan oleh sebagian besar sektor-sektor dalam perekonomian Indonesia, yaitu berkisar sebesar $10-21 \%$ terutama dari sektor-sektor yang terkait dengan perikanan dan industri pengolahan hasil perikanan yang mencapai berkisar sebesar $10,64 \%$ hingga $20,84 \%$.

Sementara itu, untuk kontribusi perubahan permintaan akhir domestik (DD) sebagai sumber pertumbuhan output total perekonomian Indonesia, pada periode kedua ini justru tidak memberikan kontribusi yang dominan (jauh lebih rendah dibandingkan kontribusi yang diberikan dari sumber perluasan ekspor (EE), yaitu hanya sebesar $3,81 \%$. Bila dilihat berdasarkan komponennya, dari kontribusi perubahan permintaan akhir domestik (DD) tersebut berasal dari sumbangan komponen perubahan konsumsi swasta (DD1) dan perubahan stok (DD2) masing-masing sebesar $1,60 \%$ dan $1,42 \%$. Rendahnya kontribusi dari sumber perubahan permintaan akhir domesti (DD) tersebut karena terdapat beberapa sektor yang memberikan kontribusi negatif, termasuk diantaranya adalah industri pengeringan dan penggaraman ikan (-9,41\%) dan industri pengolahan dan pengawetan ikan $(-1,85 \%)$, sedangkan perikanan laut dan perikanan darat justru memberikan kontribusi positif yang relatif besar, yaitu masing-masing sebesar $10,90 \%$ dan $7,97 \%$.

Pada periode kedua ini, perubahan substitusi impor (IS) memberikan kontribusi yang negatif $(-4,47 \%)$ sebagai sumber pertumbuhan output total keseluruhan sektor dalam perekonomian (perubahan IS mengurangi pertumbuhan output total). Kontribusi yang negatif dari IS tersebut terutama disumbang oleh sektor industri pengolahan lainnya $(-1,28 \%)$, sedangkan dari sektor-sektor yang terkait perikanan dan industri pengolahan hasil perikanan meskipun turut mengalami kontribusi yang negatif namun relatif rendah, yaitu berkisar sebesar $0,06 \%$ hingga $-0,20 \%$. Bahkan untuk sektor industri pengeringan dan penggaraman ikan yang mengalami kontribusi yang positif, yaitu sebesar $0,07 \%$.

Sementara itu pada periode kedua ini, kontribusi perubahan teknologi (TC) sebagai sumber pertumbuhan output total perekonomian Indonesia justru menunjukkan kontribusi yang positif, yaitu sebesar 1,86\% (tidak seperti periode sebelumnya yang menunjukkan kontribusi negatif). Kontribusi positif dari TC tersebut terutama diberikan industri pengeringan dan penggaraman ikan yang mencapai sebesar $2,86 \%$, sedangkan industri pengolahan dan pengawetan ikan justru memberikan kontribusi negatif terbesar, yaitu sebesar $-2,53 \%$. 


\section{Pergeseran dari Periode Pertama ke Periode Kedua}

Secara teoritis perubahan suatu struktur ekonomi dianggap terjadi, jika setidaknya (minimal) selama periode yang berlainan terdapat kecenderungan pergeseran sumber pertumbuhan output yang dominan (terbesar) dalam perekonomian dari sektor-sektor primer ke sektor-sektor sekundernya (Akita, 1991; Rashid dan Elameer, 1999; Akita dan Hermawan, 2000; dan Hayashi, 2005). Hal ini diperkuat dengan temuan empiris dari Kuznet (1957) dalam Jhingan (2000), Chenery (1960) dan Chenery and Syrquin (1979) menunjukkan bahwa terdapat kaitan yang erat antara pertumbuhan ekonomi dan perubahan struktur. Pertumbuhan ekonomi yang tinggi dalam jangka waktu lama akan menyebabkan secara proporsional kontribusi sektor primer terhadap output semakin menurun, sedangkan kontribusi sektor sekundernya semakin meningkat. Selanjutnya, mengingat bahwa dalam kajian ini sektor-sektor perekonomian dianalisis dalam tataran nasional (perekonomian Indonesia), maka pergeseran sumber-sumber pertumbuhan output tersebut diukur berdasarkan perubahan kontribusinya terhadap output total perekonomian Indonesia (bukan sektoral). Berdasarkan hal tersebut, dari tabel 4 dan gambar 5, dapat diketahui bahwa secara relatif bila dibandingkan antara periode pertama (1990-1995) dan periode kedua (1995-2000) ternyata kontribusi keseluruhan sektor terhadap pertumbuhan output total yang berasal dari perluasan ekspor (EE) mengalami peningkatan yang cukup besar $(66,01 \%)$, yaitu meningkat dari sebesar $32,79 \%$ pada periode pertama menjadi sebesar $89,79 \%$ pada periode kedua. Dua dari tiga sektor sebagai

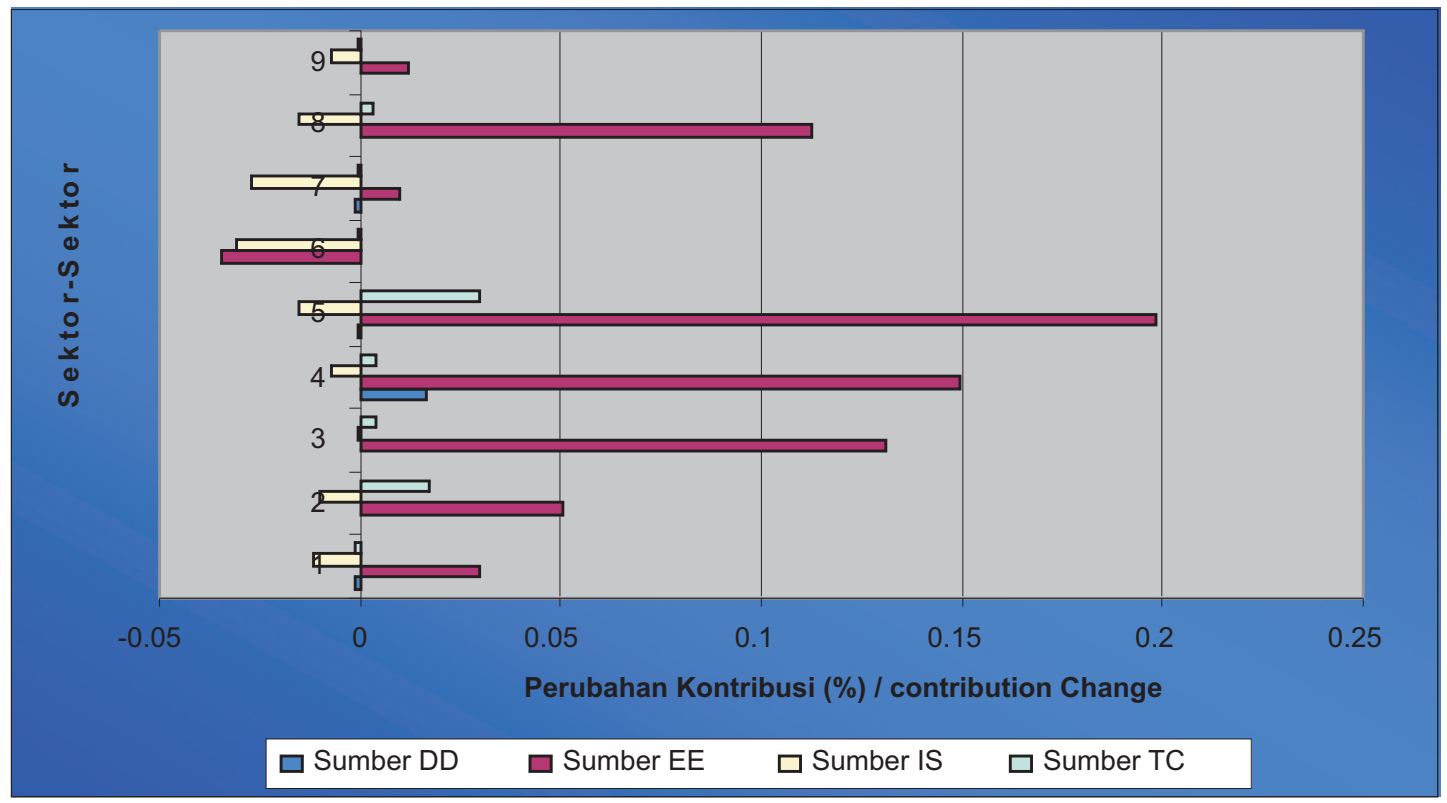

Gambar 5. Pergeseran Sumber Pertumbuhan Output Total Berdasarkan Perubahan Kontribusi Masing-Masing Sektor dari Periode Tahun 1990-1995 ke Periode Tahun 1995-2000

Figure 5. Shifting of Total Growth Source Based on the Change of Each Sector Contribution from Period 1990-1995 to Period 1995-2000 

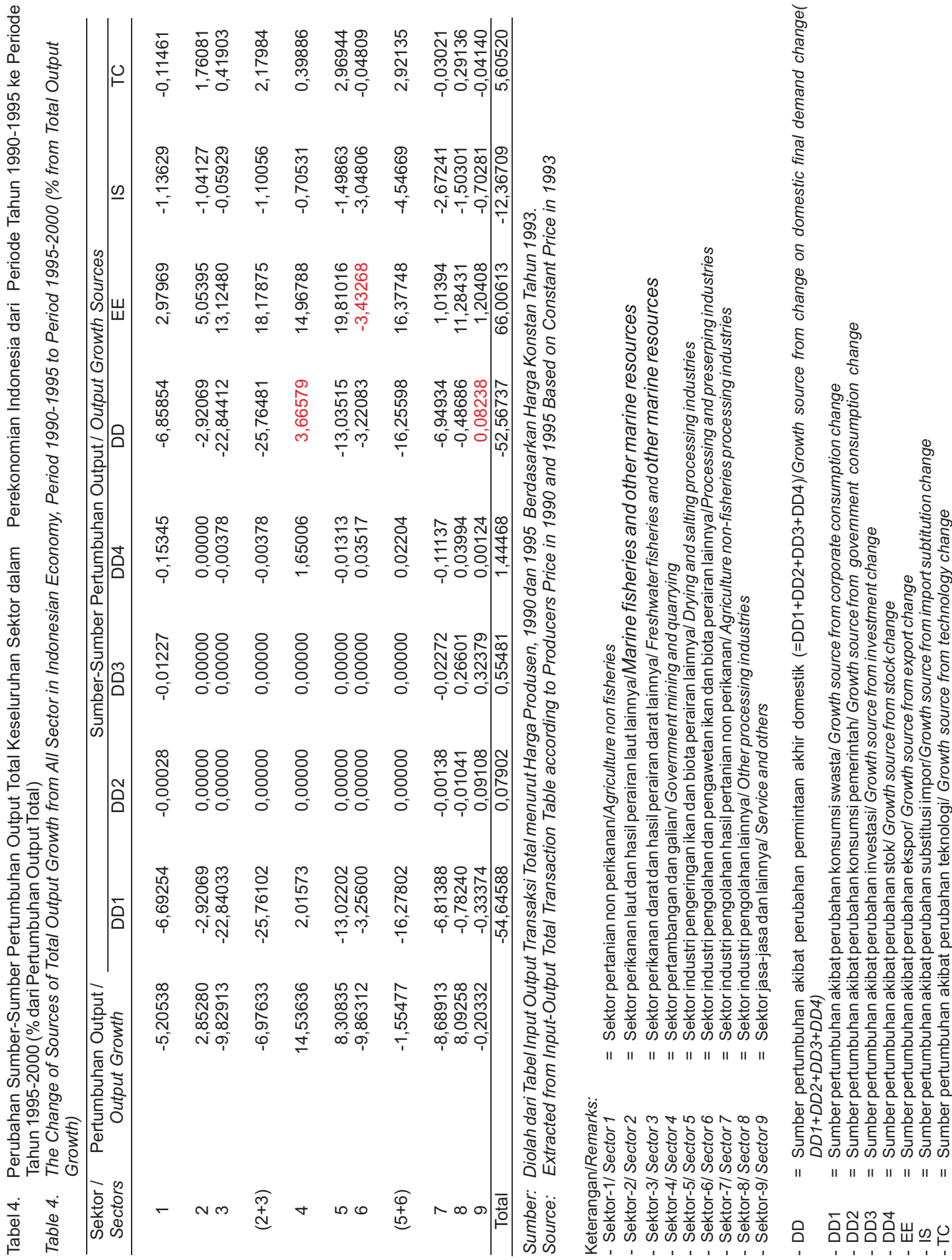
penyumbang terbesar perubahan (peningkatan) dominasi sumber EE adalah dari sektor-sektor yang terkait dengan perikanan dan industri pengolahan hasil perikanan. Kedua sektor tersebut adalah industri pengeringan dan pengawetan ikan dan perikanan darat masing-masing dengan kontribusi sebesar $19,81 \%$ dan $13,12 \%$.

Sementara itu, bila pada periode kedua ini sumber pertumbuhan yang berasal dari perluasan ekspor (EE) mengalami peningkatan dibanding periode pertamanya. Pada perubahan permintaan akhir domestik (DD) justru mengalami penurunan yang cukup besar $(-52,57 \%)$, yaitu dari kontribusi sebesar $56,38 \%$ pada periode pertama turun menjadi sebesar $3,81 \%$ pada periode kedua. Menurunnya dominasi sumber perubahan DD tersebut disumbang oleh sebagian besar sektor dalam perekonomian Indonesia. Penyumbang terbesar terhadap penurunan dominasi perubahan permintaan akhir domesti (DD) tersebut adalah perikanan darat ($22,84 \%$ ) dan kemudian diikuti industri pengeringan dan penggaraman ikan ($13,04 \%)$.

Selanjutnya dari tabel 4 dan gambar 5 , diketahui bahwa bila pergeseran (perubahan) sumber perluasan ekspor (EE) maupun DD di atas dilihat secara agregat untuk kelompok perikanan primer dan perikanan sekunder, maka meningkatnya dominasi kontribusi sumber perluasan ekspor (EE) yang diberikan kelompok primer dalam pertumbuhan output total perekonomian Indonesia ternyata tidak jauh berbeda (sedikit lebih besar) dibandingkan kelompok perikanan sekunder, masing-masing sebesar $18,18 \%$ dan $16,38 \%$ (keduanya hanya terpaut sebesar 1,8\%). Kondisi sebaliknya terjadi pada menurunnya dominasi kontribusi DD sebagai sumber pertumbuhan output total, dalam hal ini penurunan di kelompok perikanan primer lebih besar dibandingkan kelompok perikanan sekundernya, masing-masing sebesar $25,76 \%$ dan $-16,26 \%$.

\section{KESIMPULAN DAN IMPLIKASI KEBIJAKAN}

\section{Kesimpulan}

(1) Selama periode 1990-1995 secara sektoral dari kelompok perikanan primer, pertumbuhan output perikanan laut dan perikanan darat masing-masing sebesar $74,12 \%$ dan $86,99 \%$ dari sumber perubahan permintaan akhir domestik. Sementara dari kelompok perikanan sekunder, pertumbuhan output industri pengolahan dan pengawetan ikan sebesar $107,93 \%$ dari sumber perluasan ekspor, sedangkan industri pengeringan dan penggaraman ikan sebesar $54,32 \%$ dari sumber perubahan permintaan akhir domestik dan $31,75 \%$ dari perubahan substitusi impor. Selanjutnya selama periode 1995-2000 secara sektoral dari kelompok perikanan primer, pertumbuhan output perikanan laut sebesar $52,21 \%$ dari sumber perluasan ekspor dan $47,21 \%$ dari sumber perubahan permintaan akhir domestik; sedangkan perikanan darat sebesar $74,68 \%$ dari sumber perluasan ekspor. Sementara itu, dari kelompok perikanan sekunder, pertumbuhan output industri pengeringan dan penggaraman ikan sebesar $25,38 \%$ dari sumber perluasan ekspor dan $32,08 \%$ dari sumber perubahan teknologi; sedangkan industri pengolahan dan pengawetan ikan sebesar $177,84 \%$ dari sumber perluasan ekspor.

(2) Dari kontribusinya terhadap pertumbuhan output total perekonomian pada periode 1990-1995 yang didominasi sumber perubahan permintaan akhir domestik, kelompok perikanan primer yakni perikanan laut dan perikanan darat memberikan kontribusi yang terbesar pada sumber tersebut masing-masing sebesar $30,82 \%$ dan $13,82 \%$. Sementara itu, dari kelompok perikanan sekunder khususnya industri pengolahan 
dan pengawetan ikan memberikan kontribusi yang terbesar pada sumber perluasan ekspor yaitu sebesar 18,07\%, sedangkan industri pengeringan dan penggaraman ikan memberikan kontribusi terbesarnya pada sumber substitusi impor sebesar 1,57\%. Selanjutnya pada periode 1995-2000, sebesar $98,79 \%$ sumber pertumbuhan output total perekonomian Indonesia didomonasi oleh kontribusi sumber perluasan ekspor. Pada periode ini, masing-masing sektor baik dari kelompok perikanan primer maupun sekunder memberikan kontribusi terbesarnya pada pertumbuhan output total dari sumber perluasan ekspor. Dari kelompok perikanan primer, kontribusi perikanan laut sebesar $10,64 \%$ dan perikanan darat sebesar 17,52\%; sedangkan dari kelompok perikanan sekunder, kontribusi industri pengeringan dan penggaraman ikan sebesar 20,83\% dan kontribusi industri pengolahan dan pengawetan ikan sebesar $14,64 \%$.

(3) Berdasarkan pergeseran dominasi sumber pertumbuhan output total yang dikaitkan dengan kontribusi sektornya pada periode 1990-1995 dan periode 1995-2000, kontribusi perubahan permintaan akhir domestik yang diberikan sektor-sektor kelompok perikanan primer sebagai sumber pertumbuhan output total perikanan Indonesia pada periode 1990-1995 ternyata jauh lebih besar (dominan) dibandingkan sektor-sektor kelompok perikanan sekundernya. Sementara untuk kontribusi perluasan ekspor yang diberikan sektor-sektor kelompok perikanan sekunder pada periode 19952000 hanya sedikit lebih besar (tidak dominan) dibandingkan kelompok perikanan primernya. Dengan demikian selama periode analisis (1990-2000) perubahan struktur ekonomi dari dominasi kelompok perikanan primer kepada kelompok perikanan sekundernya belum terjadi secara kuat atau dapat dikatakan sebagai kondisi tengah dalam proses perubahan struktur tersebut.

\section{Implikasi Kebijakan}

Hasil analisis terhadap sumber pertumbuhan output total (nasional) menunjukkan bahwa sesungguhnya sektor perikanan (dalam arti luas) mempunyai kontribusi yang tinggi dalam pembentukan output nasional. Namun pengembangan pada perikanan primer saja, tidak cukup memadai untuk menempatkan sektor perikanan dalam arti luas sebagai penghela (prime mover) perekonomian nasional. Untuk mengatasi kelemahan tersebut, perikanan primer harus diletakkan dalam kerangka pengembangan sistem agribis nis dengan mengintegrasikannya dengan sektor komplemennya, dalam hal ini adalah dengan perikanan sekundernya (industri pengolahan hasil perikanan). Diharapkan dengan memberikan perhatian yang lebih besar pada pembangunan perikanan primer, pada gilirannya akan mampu meningkatkan kinerja pembangunan dari perikanan sekundernya. Pentingnya pengintegrasian tersebut dari kedua perikanan tersebut (primer dan sekunder) tidak hanya terbatas pada produk yang dihasil, tetapi juga pada aktivitas konsumsi dan investasi.

Mengingat pentingnya perikanan primer dan perikanan sekunder dalam perekonomian nasional, maka sudah sewajarnya bila upaya pemulihan perekonomian nasional yang dilakukan oleh Bangsa Indonesia saat ini diimplememntasikan dengan meletakkan landasan yang kuat peran pembangunan sektor perikanan dalam arti luas (perikanan primer dan perikanan sekunder). Untuk meningkatkan kinerja pertumbuhan output perikanan primer dan perikanan sekunder (industri pengolahan hasil perikanan), diperlukan penguasaan terknologi yang lebih maju, dan dengan mengefektifkan kebijakan- 
kebijakan yang mampu menarik para investor untuk berkontribusi dalam meningkatkan produktivitas dan efisiensi usaha dikedua perikanan tersebut. Disamping itu, peningkatan penguasaan teknologi tersebut diperlukan pula upaya yang dilakukan oleh segenap pelaku usaha dan pemerintah untuk secara konsisten mendorong perluasan ekspor yang secara simultan dilakukan bersamaan dengan upaya meningkatkan substitusi impor. Diharapkan melalui upaya tersebut akan mendorong transformasi ekonomi di sektor perikanan secara luas ke arah industrialisasi yang lebih matang (mature) dimana keterkaitan antara perikanan primer menjadi semakin erat dengan perikanan sekundernya serta dengan sektorsektor lainnya dalam perekonomian nasional, dan pada saatnya nanti peranan perikanan sekunder semakin kuat sementara peranan perikanan primer juga secara proporsiaonal tetap semakin meningkat dalam perekonomian nasional.

\section{DAFTAR PUSTAKA}

Akita, T. 1991. Industrial Structure and The Sources of Industrial Growth in Indonesia: An Input-Output Analysis Between 1971 and 1985, Asian Economic Journal, vol. 5, no. 2: 139-158.

Akita, T. and Hermawan, A. 2000. The Sources of Industrial Growth in Indonesia, 1985-1995: An Input-Output.

Badan Pusat Statistik. 2000. Kerangka Teori dan Analisis Tabel Input-Output. Biro Pusat Statistik. Jakarta.

Badan Pusat Statistik. 2004a. Tabel InputOutput Indonesia 2000. Jilid I, II dan III. Badan Pusat Statistik. Jakarta.

Badan Pusat Statisitik. 2004b. Indikator Ekonomi Makro Sektor Kelautan dan Perikanan Tahun 1990 - 2000. Buku I. Badan Pusat Statistik. Jakarta.

Biro Pusat Statistik. 1999. Tabel Input-Output Indonesia 1995. Jilid I, II dan III. Biro Pusat Statistik. Jakarta.
Biro Pusat Statistik. 1994. Tabel Input-Output Indonesia 1990. Jilid I, II dan III. Biro Pusat Statistik. Jakarta.

Chenery, H.B. 1960. Pattern of Industrial Growth, American Economic Review, September 1960, 50, pp. 654-624.

Chenery, H.B. and Syrquin, M. (1979). A Comparative Analysis of Industrial Growth. In Economic Study, ed. by Chenery, H.B., Robinson, S., and Syrquin, M. New York: Oxford University Press.

Choeryanto, S. 2002. Ekonomi Indonesia: Penurunan dan Langkah Penanggulangan. Lembaga Penerbit Fakultas Ekonomi Universitas Indonesia, Jakarta.

Dahuri, R. 1999a. Membangun Kelmabli Perkeonomian Nasional Melalui Pembangunan Perikanan dan Kelautan Secara Optimal dan Berkelanjutan: Masukan untuk GBHN 2000, Naskah Akademik Usualan Departemen Perikanan dan Kelautan, IPB, disampaikan kepada Sembilan Fraksi MPR-RI Sidang Umum MPR-RI 1999, PKSPL-IPB, Bogor.

Dahuri, R. 1999b. Visi dan Arah Pembangunan Kelautan Indonesia Memasuki Abad 21. Seminar Kelautan. Departemen Pekerjaan Umum, Jakarta, Juni 1999.

Dahuri, R. 2003. Kebijakan dan Strategi Pembangunan Kelautan dan Perikanan. dalam Menggapai Cita-Cita Luhur: Perikanan Sebagai Sektor Andalan Nasional. Edisi ke II, 2003. Ikatan Sarjana Perikanan Indonesia (ISPIKANI) bekerja sama dengan Departemen Kelautan dan Perikanan (DKP), Jakarta.

Forssell, O. 1988. Growth and Changes in the Structure of the Finnish Economy in the 1960s and 1970s. In Input Output Analysis: Current Development, ed. Maurizio Ciaschini. London: Chapman and Hall. 
Hayashi, M. 2005. Structural Changes in Indonesian Industry and Trade: An InputOutput Analysis. The Developing Economies, Vol. XLIII, No. 1. Institut of Developing Economies, IDE JETRO.

Jhingan, M.L. 2000. Ekonomi Pembangunan dan Perencanaan. Edisi ke delapan, RajaGrafindo Persada, Jakarta.

Kaneko, Y. 1984. Price Deflator in InputOutput Tabel: Its Formulation and Its Application. A Quantitative Study on the Medium/Long-Term Prospects of the Indonesian Economy. Bappenas. Ocassional Paper Series No. 45, Agustus 1984.

Kusumastanto, T. 2001. An Evaluation of Investment Strategy for the Development of Brackish Shrimp Aquaculture Industry in Indonesia. Jurnal Teknologi Perikanan dan Kelautan. Vol. 1 No. 4. Hal.: 1-28.
Liu, A. and Saal, D.S. 1998. Sources of Structural Change and Output Growth of South Africa's Economy : 1975-1993, Paper, Middlesex University Business Schooll.

Nazara, S. 1997. Analisis Input Output. Lembaga Penerbit Fakultas Ekonomi Universitas Indonesia. Jakarta. 130 halaman.

Nikijuluw, V.P.H. 2005. Politik Ekonomi Perikanan: Bagaimana dan Kemana Bisnis Perikanan?. Feraco, Jakarta.

Rashid, Z.A. dan Elameer, A.E. 1999. Sources of Industrial Growth Using the Factor Decomposition Approach: Malaysia 1978-1987, The Developing Economies, XXXVII, 2.

Susanti, H., Ikhsan, M. dan Widyanti.1999. Indikator Makro Ekonomi, Lembaga Penerbit Fakultas Ekonomi Universitas Indonesia, Jakarta. 
